\title{
INTERVIEW WITH JAMES N. GREEN
}

\author{
Entrevista com James N. Green
}

Entrevista con James N. Green

\author{
INTERVIEW WITH: \\ JAMES N. GREEN ${ }^{I^{*}}$ \\ INTERVIEWERS: \\ MARTINA SPOHR ${ }^{\mathrm{II} * *}$ \\ RONALD CANABARRO ${ }^{I I * * *}$
}

DOI: https://doi.org/10.1590/S2178-149420210211

'Brown University in Providence, Rhode Island, United States.

*Full Professor of Brazilian History and Culture at Brown University in Providence, Rhode Island, the author or co-editor of eleven books on Brazil, and the founder and National Co-coordinator of the U.S. Network for Democracy in Brazil. (james_green@brown.edu)

(D) https://orcid.org/0000-0002-7309-0751

"Fundação Getulio Vargas - Rio de Janeiro (RJ), Brazil.

**PhD in Social History from the Universidade Federal do Rio de Janeiro. She is currently an Adjunct Professor, Coordinator of the Social Sciences Course at the School of Social Sciences of Fundação Getúlio Vargas, Rio de Janeiro, and serves as a Visiting Professor Abroad at the University of Hawaii at Manoa as a CAPES/PrInt fellow. (martina.spohr@fgv.br)

(D) https://orcid.org/0000-0003-1461-5367

"'Universidade Federal do Rio de Janeiro. Fundação Getúlio Vargas - Rio de Janeiro (RJ), Brazil.

*** Bachelor and Master in History from Universidade de Passo Fundo. PhD student in History, Politics, and Cultural Property by Fundação Getúlio Vargas. He works as a Technician in Educational Affairs at Universidade Federal do Rio de Janeiro (ronaldcanabarro@gmail.com).

(D) https://orcid.org/0000-0002-3548-3968

Interview granted on February 25, 2021, by e-mail. Article received on March 1st, 2021 and approved for publication on April 1t, 2021. 


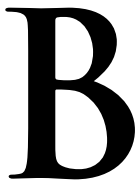

orn on November 22 ${ }^{\text {nd }}, 1951$, in Baltimore, Maryland, United States. He graduated in Political Science from Earlham College, Indiana in 1972. Three years later, in 1975, he moved to Latin America, coming to live in São Paulo. There he became one of the founding members of the Somos de Afirmação Homossexual Group, in addition to working with the student movement and being one of the intellectuals who denounced the Brazilian military dictatorship internationally. Years later, back in the United States, he earned his PhD in Latin American History at the University of California, Los Angeles, between 1992 and 1996, the year he was hired as Assistant Professor at California State University, Long Beach, remaining until 2004. From 2005, he became a professor at Brown University, Rhode Island, where he works today and, since 2013, he is a full professor occupying the chair of History of Latin America. Author of dozens of academic articles and several books, of which the following stand out: Além do carnaval: a homossexualidade masculina no Brasil do século XX (2000); Homossexualismo em São Paulo e outros escritos (2005), a book organized by him; Frescos Trópicos: fontes para a história da homossexualidade masculina no Brasil (19701980), organized with Ronald Polito (2006); Apesar de Vocês: a oposição e a ditadura militar brasileira nos Estados Unidos, 1964-85 (2009); Homossexualidade e a ditadura brasileira: Opressão, resistência e a busca da verdade, organizado em conjunto com Renan Quinalha (2014) and Revolucionário e Gay: a vida extraordinária de Herbert Daniel, pioneiro na luta por democracia, diversidade e inclusão (2018). He has dedicated his research with emphasis on the History of Brazil Republic, acting mainly on the following themes: military dictatorship, Latin America, Brazil, human rights, and homosexuality.

Interviewers: Professor James N. Green, you are a Brazilianist and at the same time one of the political activists who helped found the LGBT movement in Brazil in the late 1970s and early 1980s. While you lived in Brazil from 1976 to 1981 and studied at the University of São Paulo, you were also involved in the movement against the dictatorship. Your experience living in Brazil led to the publication of your first book on the history of male homosexuality in Brazil. In practical terms, how have you balanced your political activism with your academic production?

Green: I became involved in the LGBT movement in the United States in 1973 immediately after finally accepting my own homosexuality. I had already been participating actively in the movement against the U.S. intervention in Vietnam, and had even been arrested several times in protests in Washington, D.C. in 1971 during non-violent civil disobedience actions against the escalation of the war by the Nixon administration (1969-74). Simultaneously with 
becoming involved in Gay Activists Alliance in Philadelphia in 1973, I also began working with a group in Washington, D.C., called the Committee against Repression in Brazil. It was founded in 1971 by a political exile to organize a protest against the visit of President-General Médici to the Nixon White House in 1971. One of my first activities was to join a picket line in front of the Brazilian embassy on September $7^{\text {th }}, 1973$, denouncing torture and repression in Brazil.

At the same time, I sought out leftists within the LGBT movement to work with them, and in 1974 I moved to San Francisco, which was an important center of progressive LGBT politics in the United States. There, I joined the June $28^{\text {th }}$ Union, a collective of socialist gay men, who were trying to bring a progressive agenda to the LGBT movement. By this time, I was also deeply involved in working against the U.S. government's support for the Pinochet dictatorship in Chile. In 1975, I organized a public event, "Gay Solidarity with the Chilean Resistance," which brought together 300 people from the LGBT community in San Francisco to protest the U.S. involvement in the 1973 coup in Chile.

So, when I arrived in Brazil in 1976, I already had experience in connecting the political agenda of the Left with issues being raised by LGBT activists. I brought that vision to Somos: Grupo de Afirmação Homossexual, the first political LGBT organization in Brazil.

A decade later, when I returned to the United States and decided to get a doctoral dissertation to become a professor of Brazilian history, I chose to study the history of male homosexuality in twentieth-century Brazil as a political act. There wasn't a rigorous historical study on the topic in Portuguese nor in English, and it was a way of bringing the issue of full rights for LGBT people into academia. My study, I believe, was the first comprehensive social history of male homosexuality in Latin America, even though the focus of my first book, Beyond Carnival (Além do Carnaval), was Rio de Janeiro and São Paulo.

Interviewers: How do you evaluate the political changes that the LGBT, feminist, Black, and people with disabilities movements have achieved since you began your activities in Brazil in 1978?

Green: The changes have been monumental. One has to remember that the feminist, Black, and LGBT movements, and, later, the movement in defense of people with disabilities, emerged during the dictatorship in the 1970s. It would take another decade for the armed forces to finally leave power. The process of liberalization (distenção) initiated by the government of President General Geisel in 1974 was designed to be very slow and controlled, but it was almost immediately pushed forward by popular opposition to the dictatorship. One reflection of this was the resounding defeat of the government party (ARENA) in the 1974 elections by the opposition (MDB). 
New progressive publications produced and consumed by the post-1968 generation, which I call "Generation 77," allowed for there to be a much broader debate not only about how to defeat the dictatorship, but also about other questions that were becoming important in Brazil at the time. Importantly, the reorganization of the student movement and the beginning of street protests in 1977 gave confidence to other social movements. This opened the door, in my opinion, for the United Black Movement to publicly criticize the discourses of racial democracy, which had been the hegemonic way of understanding race in Brazil. The Black movement was crucial for pointing out how systematic racism structured Brazilian society. Organizing around the United Nations events in 1975 focusing on the Year of Women, allowed Brazilian feminists to have more visibility and offer critiques both of sexism and the patriarchy within the Brazilian Left and society as a whole. It also provided the space for them to organize and disseminate their ideas. Equally important was the new importance of a more radical union movement, challenging the dictatorship's economic and labor policies, which would eventually lead to the formation of the Workers' Party (Partido dos Trabalhadores - PT).

The LGBT movement came into being within this context. It faced three major challenges: confronting long-term discriminatory notions pervasive in Brazilian society that viewed same-sex romantic and sexual relations as pathological and immoral; the lack of experience in political organizing around LGBT issues; and the incomprehension by most sectors of the leftwing anti-dictatorship forces about the relationship between the movement to end military rule and the fight for expanded democratic rights articulated by women, Black activists, and the LGBT movement.

From tiny LGBT groups that struggled to survive in the early 1980s, and which faced a tremendous conservative backlash when AIDS became a major issue, activists, nonetheless, managed to sustain pockets of resistance through the 1980s and early 1990s. A national movement exploded in the mid-1990s, pushing a comprehensive agenda demanding full democratic rights and equal participation in society and protection under the law.

In recent years, millions have mobilized in annual pride parades throughout the country. The movement has been a major factor in creating social and cultural changes that have had a decisive effect, for example, on the Federal Supreme Court, which has issued a series of decisions guaranteeing equal rights, including the right to adoption and marriage, and protections against homophobia and hate speech. These reflect the deep changes in social attitudes toward homosexuality that have taken place in Brazil since the founding of the movement during the twilight of the dictatorship. In spite of recent attempts to push back LGBT rights, we are winning the battle for the hearts and minds of Brazilians, something inconceivable when we founded the movement four decades ago. 
Interviewers: In what ways did your political experiences and your understanding of social movements impact on the ways in which you conducted your research?

Green: When I decided to write a social history of homosexuality, I understood that it could serve as a very useful tool for activists who had no historical knowledge of the repression and discrimination against homosexualities in Brazil over the course of the twentieth century. In one respect, the book was designed to give activists a sense of how people countered hegemonic heteronormative frameworks in daily acts of resistance and in moments during the year, such as Carnival celebrations, when they created spaces that permitted freer expressions of non-normative gender performances. It was also important to capture the voices of ordinary people who challenged oppressive structures in the past as an inspirational example for people doing so in the present. In this regard, my research was consciously political and designed not just to document history but to transform society through the example of those people I profiled in the book.

Interviewers: Among your books, one that is considered obligatory reading about homosexualities in Brazil is Beyond Carnival: Male Homosexuality in Twentieth-century Brazil (University of Chicago, 1999) that was published in Portuguese as Além do Carnaval: a homossexualidade masculina no Brasil do século XX (Editora da UNESP, $2000,2^{\text {nd }}$ edition 2019), based on your doctoral dissertation. More recently, you have produced two other important contributions to the discussion of homosexualities and the military dictatorship. One is the biography of Herbert Daniel, Revolucionário e gay: vida extraordinária de Herbert Daniel — pioneiro na luta pela democracia, diversidade e inclusão (Civilização brasileira, 2018), which was published in English as Exiles within Exiles: Herbert Daniel, Gay Brazilian Revolutionary (Duke University Press, 2018). The other was Ditadura e Homossexualidades: Repressão, Resistência e a Busca da Verdade, co-edited with Renan H. Quinalha (Editora da UNESP, 2014), was linked to work of the National Truth Commission.

What were the difficulties you faced in finding sources for your books?

Green: Each project had difficulty challenges. In doing research for Beyond Carnival, I had to be very creative in finding documents. Because there are no laws explicitly prohibiting homosexuality, since the crime of sodomy was eliminated from the criminal code in 1830, it was harder to find specific legal cases, for example, in which the state explicitly repressed people for what were considered sexual transgressions. The archives for the violations of the specific codes used to arrest people — public indecency, vagrancy, and public affronts to propriety — were not easily accessed when I searched the National Archive in 1993 and 1994, 
as they had not been indexed. While doing my research in Rio and São Paulo on the late nineteenth and the early twentieth century, I took days at a time going through legal cases to find one or another case involving same-sex sexuality. Based on my knowledge of what happened to middle-class gay men in the 1960s when challenged by the police, it seems likely that there were no records because there were no formal changes levelled against many men accused of performing non-normative gender behavior in public. Effeminate men in certain sections of the city were constantly vulnerable to arrest, but they were rarely charged with a crime. Instead, they stayed in jail for a few days or paid bribes to the police to avoid incarceration. It is an example of social repression without an archival trace, so one can only speculate or use a very small number of cases to extrapolate about a much broader clandestine phenomenon that left no record.

Fortunately, I managed to interview a social network of gay men from the 1960s who lived in Rio and produced a small bulletin, $O$ Snob, that had been donated to the Edgard Leuenroth Archives at the State University of Campinas. I traced down the editor of the mimeographed publication and interviewed him. He then facilitated my interviews with a whole group of men who relayed their lives from the 1950s and 60s, which helped me tremendously. At the same time, I spent many hours going through magazines, newspapers, and other media looking for glitters of gold, which I occasionally found.

Having learned the value of oral histories, I employed them in my second book, We Cannot Remain Silent: Opposition to the Brazilian Military Dictatorship in the United States (Duke University Press, 2009), which was translated as Apesar de vocês: a oposição à ditadura militar nos Estados Unidos (Companhia das Letras). There, I faced the opposite problem - too many sources. I ended up writing a book much longer than the U.S. publishers would allow, and I painfully had to cut one-third of the content. If I had collected two boxes of copied documents for Beyond Carnival, I collected more than a dozen for this second book.

My third book about Herbert Daniel was, to a certain extent, a compromise between the first and the second ones regarding sources and the use of oral histories. However, when researching the life of a person who spent six years underground and who learned not to reveal secrets of his political past, those who knew him while he was in the guerrilla movement many times could not give me a lot of information because revolutionaries learned to know as little about others as possible and forget what was not necessary to remember. Others, whom I wanted to interview, had died, and so the book has many lapses and unfilled spaces.

The collection of articles, Ditadura e Homossexualidades: Repressão, Resistência e a Busca da Verdade, was a different matter altogether, as it was an effort to bring togeth- 
er the research nine scholars who were working on different aspects of the dictatorship with the purpose of showing those who valued the work of the Truth Commission that the lack of democratic rights and the arbitrary nature of the military regime intensified the repression of homosexuality during the years of authoritarian rule. As a result of that collection, we ensured that there was a chapter of the Final Report of the Truth Commission that summarized and synthesized the research published in the book. We were also able to include material in the final reports of the São Paulo and Rio de Janeiro Truth Commissions as well.

Interviewers: How do you think these publications can help us to understand beyond the military period, even drawing parallels with current politics?

Green: Brazil is currently passing through an extremely dangerous period when democracy is being directly challenged by the authoritarian hard-right government in power. Those who understand what military rule was like understand how this is a threat to freedom, liberty, and democracy. Unfortunately, there is a sector of Brazilian society that does not know its country's past and therefore thinks it is acceptable when public officials defend torture, praise the authoritarian period, support homophobic, racist, and misogynist positions, and do not respect the rule of law. Beyond Carnival reveals the systematic homophobia that I documented throughout the twentieth-century that still pervades Brazilian society today, in spite of tremendous changes in recent years. Similarly, We Cannot Remain Silent registered the ways that a small group of exiles, academics, religious figures, and others organized resistance to the Brazilian dictatorship in the United States in the 1960s, 70s, and 80s, something that applies to the current situation in which throughout the world people are mobilizing against the current government. My biography about Herbert Daniel details life under the dictatorship in Brazil, how people resisted, and then how they fought for a new, democratic Brazil that expanded rights for LGBT people among others. All three books in many ways look at the past to understand the present.

Interviewers: In 2016 you headed a petition campaign that alerted the international academic community about the threat to democratic order in Brazil. In a way, it foresaw the growth in conservative politics and attacks on the rights of workers and historically marginalized groups. In one of your interviews you stated that Brazil in 2016 was very close to Brazil in 1961, even suggesting that the struggles and resistance of historically marginalized groups would have to be expanded. With the victory of current President Jair Bolsonaro in 2018, many historically won rights are gradually being lost. 
How did the scenario you warned about in 2016 lead to the present situation, and how do you see the resistance processes it has produced?

Green: That is a big question that requires a very long answer. I will try to be concise. I believe that Brazil began to polarize in 2006 during the first Lula administration, but since he was very successful as president, and the economy did well, it wasn't as obvious. Lula managed to win over sectors of the elite who saw in his policies measures that benefited them as well. Moreover, they couldn't present popular alternatives: Serra, Alckmin were not dynamic and popular politicians.

The Right faced a similar problem in 1961. Although Jânio Quadros got the endorsement of the conservative União Democrático Nacional (UDN), he was in many ways a rightwing populist who distanced himself from that party and tried to govern alone. Since the Congress was divided — one-third left, one-third center, and one-third right, he found it very difficult to enact legislation, and his rejection of the UDN meant that he didn't have strong institutional, partisan support in Congress. After the crisis of his resignation and the assumption of João Goulart to the presidency in 1961, the Right realized that once again the pro-Vargas forces had won control of the State. As Goulart moved to the left in 1963 and retained popular support, they feared that his possible successor in 1965, Juscelino Kubitschek, although from the Center, would likely continue populist politics and that the Right once again would not gain access to the State.

When Dilma Rousseff's popularity waned after the 2013 mobilizations and she won the presidency by a narrow margin the next year, the Right saw that they had the chance to seize power. It was a two-pronged operation: impeach Rousseff and through Lava-Jato prevent Lula from being a candidate in 2018.

From 1961 to 1964, there was an increase in political mobilizations in Brazil that provoked a polarization as workers, peasants, and progressive forces. As far as the Right was concerned, this meant that the Left was gaining ground and more systematic changes might actually take place in Brazil. At the end of the day, Goulart did not propose revolutionary transformation, but the Right, economic elites, the military, and the U.S. government, among others, presented Goulart as a proto-communist. They insisted that the Communist Party was on the verge of coming to power. This was both at the time and with historical hindsight a ridiculous proposition, but this argument carried weight at the time when the Cold War was at its height.

Lula's and Dilma's governments implemented a series of social democratic reforms Bolsa Familia, expanded access of poor people, especially Afro-Brazilians, to higher education, labor rights for domestic servants, inviting Cuban doctors to serve rural areas where newly graduated physicians from middle and upper-classes refused to work, among many other measures. Their governments were no more revolutionary than was the administration of Goulart, 
but the Right created a panic to justify impeachment, the imprisonment of Lula, and the need for a savior to rid the country of corruption and twenty-first century "communism."

Another very important element in the two processes was the discourse about family and morality in 1961-64 that has been recycled and updated to claim that gender politics, the LGBT movement, and feminism are threatening the family and the nation. The visibility of queer people, in large part due to the successes of the movement, has engendered a conservative backlash. This time it is led not just by the rightwing of the Catholic Church, as was the case in the early 1960s, but also by Evangelical Christians with their conservative notions about gender and sexuality.

Interviewers: Do you consider that the opposition movements in Brazil and in the United States are managing to confront the increase in conservative forces?

Green: Bolsonarismo in Brazil and Trumpism in the United States are two representations of new complex international trends of the far right that tap into the anxieties of people in the lower and middle classes, whose lives have been disrupted by dramatic changes in national and international economies and forms of disintegration in the quality of life in capitalist countries. These people respond to appeals for a return for a non-existent past that allegedly was better than the present.

In the case of Brazil, it is the argument that things were better during the dictatorship because there was law and order, a traditional family, and morality. Trump's slogan, "Make America Great Again," refers to some undetermined moment in the past, presumably before Obama was president, when the United States was a great and proud nation that was corrupted by the Democrats and their policies that support the rights of African-Americans, Latinxs, LGBT people, and favor some sort of social democracy. Both movements, in part through balkanized social media, real fake news, and the atomization of U.S. and Brazilian society, in addition to racism in the United States and anxieties about the popular classes in Brazil, have developed mass followings which are extremely dangerous to democracy.

Although Biden won the U.S. elections, which is a hopeful sign in Brazil indicating that Bolsonaro can too possibly be defeated in 2022, the United States is still tremendously polarized. The question for Brazil is whether the strongest candidate of the Left can manage to gather enough support from democratic anti-Bolsonaro forces to defeat him in the 2022 elections.

Interviewers: In 2018, you founded the U.S. Network for Democracy in Brazil at the Columbia Law School with the participation of 200 scholars of Brazil and Brazilian activists living in the United States. Why was it necessary and what has it accomplished over the last two years? 
Green: In 2016, even prior to the impeachment of President Rousseff, groups of Brazilians living in the United States, and around the world, began mobilizing to defend democracy in Brazil, which seemed seriously threatened by the growing strength of the Right and its authoritarian discourses. In addition, the Brazilian Studies Association (BRASA), an international organization of scholars of Brazil, headquartered in the United States, passed a resolution that drew attention to the erosion of democracy in Brazil, especially related to the arbitrary actions of Sérgio Moro during the Lava Jato (Car Wash) investigation. Subsequently, with the leaking of communications of Sérgio Moro showing that he ignored due process and was biased in favor of the prosecution of Lula, it has become clear that the suppositions articulated in the resolution were both accurate and prescient.

The new measures of the Temer government, which stifled academic freedom and began the process of dismantling the major gains of the Lula/Dilma governments, engendered significant alarm internationally, and BRASA spoke out on numerous occasions against the attacks on Brazilian universities. Concurrently, the number of collectives and groups in the United States grew, protesting against the assassination of Marielle Franco in early 2018, joining the international \#Elenão campaign against Bolsonaro's election, and educating the U.S. public about the growing dangers from the rise of the far-Right in Brazil.

Bolsonaro's election, which was widely covered in the U.S. press, led many people to recognize the need to establish a democratic, non-partisan, and decentralized national network of activists and academics to disseminate information in the United States about the nature of the new Bolsonaro government. Since it was founded in 2018, the U.S. Network for Democracy in Brazil, with more than 35 affiliated groups and connections in 45 states at 230 colleges and universities, has grown to count on 1,500 supporters. In February 2020, we opened the Washington Brazil Office to educate people in the U.S. Congress about the situation in Brazil and to support the social and popular movements that are currently under attack.

Our most recent activity has been issuing a Policy Paper on Brazil directed toward the Biden administration that focuses on ten major issues in Brazil from the deforestation of the Amazon to the violation of human rights with specific policy proposals regarding how to respond to the Bolsonaro government. The policy paper is currently circulating among members of the Biden administration and the U.S. Congress as an important vehicle to educate policymakers about the situation in Brazil.

Interviewers: Brazil had, for the first time, a small but significant number of transvestite, black, and indigenous representatives who were elected in the last municipal elections. How do you evaluate this moment and the impact of this representativeness? 
Green: This is a very important new phenomenon, reflected in part in the development of a more sophisticated Left, which understands that Brazil is a diverse country and that diversity can and should be represented in city, state, and national legislatures. It's a sign of the strength of the LGBT movement, feminism, and Black consciousness.

I would guess that if someone did a careful survey, they would find that the educational policies implemented when Fernando Haddad was Minister of Education and public and private universities were opened up to children of the poor and the working class for the first time in the history of Brazil, it produced not only a new generation of candidates but also people who got involved in their electoral campaigns or supported their election.

Interviewers: Concomitant to all this, in 2019/2020, we were caught by surprise with a world-wide pandemic that has had unprecedented impacts in recent history. Given this scenario, and based on his academic and political experience in the USA and Brazil, some questions arise:

What are the possible parallels of how American and Brazilian policies have dealt with the pandemic issue?

Green: Unfortunately, both countries had leaders when the pandemic broke out that were totally unprepared to respond to the challenge of preventing the spread of the infection and creating the conditions to adequately treat those who caught the virus and became sick. Both presidents dismissed the virus as a simple cold, refused to promote the use of masks, suggested medicines with no curative values, and refused to address the economic problems that the pandemic created because they did not understand that the way to get the economy to work was to control the pandemic.

Brazil has a population of more than 200 million inhabitants. As of this interview, there have been 400,000 deaths. The United States has a population of 330 million inhabitants and 500,000 deaths, making the rate of deaths in Brazil second only to those in the United States. Both presidents are responsible for a form of genocide against their populations and should be held accountable.

After the vaccine was developed, instead of elaborating a plan to ensure that people in the United States would get the vaccine quickly, Trump spent all of his time and energy insisting that he won the elections. (I predict that Bolsonaro will copy many of Trumps discourses about electoral fraud before and after the results of the 2022 elections). Bolsonaro's policies have been a total disaster. Even with the public Unified Health System (Sistema Único de Saúde - SUS) and the experience of massive vaccination campaigns in Brazil, Bolsonaro has been incapable of getting the vaccination program off the ground. Many more will die as a result. 
Interviewers: Concerning COVID-19, and possible parallels with other pandemics, such as HIV in the 1980s and 1990s, for example. Do you consider that the LGBTI and Health movements were/are part of the elaboration of public health policies?

Green: One of the important contributions that Brazil made to the world fight against AIDS in the 1990s was to force international pharmaceutical companies to allow generic drugs to be produced in the Global South to combat HIV and to offer treatments to people living with AIDS. This only came as a result of a politicized movement in Brazil, that emerged in the mid1980s, a half decade or so after the founding of the "Homosexual Movement" in Brazil, as it referred to itself in the early years. The movement, founded during the slow-motion process toward democratization, created a new positive discourse about homosexuality that many of the first AIDS activists brought to the fight to force the State to address the AIDS crisis. Among those who joined in that struggle was Herbert Daniel, who, like many people of his generation didn't trust the State and fought to oblige it to change its policies and seriously address the pandemic. He also contributed to the movement with a powerful slogan: the best cure for AIDS is solidarity.

Another powerful movement that emerged during the process of democratization in the 1970s brought together progressive members of the medical profession, public health specialists, and popular grassroot organizations that mobilized to demand that the State set up a universal health care system. The process of lobbying the Constituent Assembly in 1987-88 that wrote a new constitution resulted in the creation of the public health system (SUS), which has been an essential line of defense against COVID-19.

Unfortunately, the current government with its neo-liberal policies is trying to dismantle this tremendous gain of the popular classes. Both in the movement to fight against AIDS and in the current efforts by medical practitioners dealing with the pandemic is an underlying understanding of the importance of good public health policy. The disasters of the current government in not effectively dealing with the pandemic have the possibility of raising the consciousness of many people who might have supported Bolsonaro in the last election but are coming to realize, like many in the United States regarding Trump, that his policies are genocidal.

Although it is still impossible to predict the immediate future based on the past, one of the important ways in which a strong national LGBT movement emerged in the 1990s was using the work of educating people about HIVIAIDS to raise broader issues about affirming one's sexuality, respecting one's body, and demanding full and equal rights. In other words, AIDS helped politicize many people; perhaps in different ways, people's experience with the current government and COVID-19 might produce similar results. 
Interviewers: Finally, we would like to know your opinion about the recent elections for president in the United States in 2020 and the electoral projections for Brazil in 2022 in a comparative perspective, considering the impacts of the pandemic and its political consequences.

Green: As suggested in my response to the previous question, regarding the defeat of Trump, there is no doubt that his inability to deal effectively with the pandemic was a major factor in his electoral loss. Still, there were many other reasons: a desire to have a "normal president" who wasn't upsetting the world every day with his tweets; strong opposition to the racist, nationalistic, and xenophobic policies of the Trump administration; the concern about the denial of global warming and the environmental dangers we are facing; outrage about the corruption connected to his family, etc. The list is a long one, and it is not unlike the sentiment against Bolsonaro. However, Trump's mishandling of the pandemic stood out for many people who did everything possible to ensure that they voted and their vote counted.

The only "successful" thing that Bolsonaro has done has been the small amount of financial assistance he provided people last year, which seems to have resulted in a slight increase in his popularity throughout the country, including the Northeast, which was the stronghold of the opposition to him in the 2018 election. But this popularity seems to have diminished in recent months, and I'm not sure that it will engender much significant long-term support from many who voted for the Left in recent elections.

The major question is the composition of the forces in opposition to Bolsonaro in the first round of the 2022 elections. Can the Center-Right manage to reconfigure itself through the leadership of João Doria, Luciano Huck, or another personality to get more votes than the strongest force on the Left to run in the second round against Bolsonaro? Will the PT's candidate, and the coalition built around the campaign, manage to outpoll the Center-Right to challenge Bolsonaro? Or will another Center-Left politician successfully do that?

Biden, who represents the very moderate wing of the Democratic Party, managed to pull forces together to be the unity candidate to defeat Trump. It is still not clear who that candidate might be in Brazil. However, it is far too soon to know. As a professor of Brazilian history, I appreciate the unpredictable nature of politics in the country, from the strange adventure of the Portuguese royal family fleeing Napoleon's forces in 1807 and arriving in Rio de Janeiro in 1808 to the fact that a working-class leader with primary education managed to become the president of Brazil, get reelected, and leave office with 80 percent popularity. Who could have imagined that a female guerrilla fighter could become the president of Brazil or that a second-rate captain in the army could assume that office? A million things could happen between now and late 2022. In Brazilian politics, a year can be equivalent to a decade. So, it is very hard to know what the future can bring. 
Unfortunately, the current situation makes me very sad because I love Brazil's culture and its people. The year 2021 is going to be very difficult because the pandemic is not under control. Many people have given up on taking the precautions to fight it, and the vaccination program is still precarious. There will be much suffering, and the economy will be slow to recover, causing even more hardship for the poor and working classes. However, in the long run, I am optimistic, as I believe that the social movements and progressive forces that defeated the dictatorship and expanded democracy in subsequent decades will also defeat the authoritarian period that Brazil is currently experiencing. I am hopeful that the country will return to the conditions that will allow progressive forces to achieve measures to establish social justice and equality throughout the country.

Conflicts of interest: nothing to declare.

Funding: none.

Authors' contributions: Spohr, M.; Canabarro, R.: Project Administration, Conceptualization, Edition.

\section{REFERENCES}

GREEN, J. Beyond Carnival: Male Homosexuality in Twentieth-Century Brazil. v. 1. Chicago: University of Chicago Press, 1999.

GREEN, J. Além do Carnaval: a homossexualidade masculina no Brasil do século XX. v. 1. São Paulo: UNESP, 2000.

GREEN, J. Revolucionário e gay: A extraordinária vida de Herbert Daniel? Pioneiro na luta pela democracia, diversidade e inclusão. 1. ed. v. 1. Rio de Janeiro: Civilização Brasileira, 2018.

GREEN, J. N.; QUINALHA, R. (org.). Homosexuality and the Brazilian Dictatorship: Oppression, Resistance, and the Search for Truth. 1. ed. v. 1. São Carlos: EdUFSCar, 2014. 320p.

GREEN, J. Apesar de vocês: a oposição à ditatdura brasieira nos Estados Unidos, 1964-85. v. 1. São Paulo: Companhia das Letras, 2009. 